\title{
Development and Testing of a Groundwater Management Model for the Faultless Underground Nuclear Test, Central Nevada Test Area
}

Prepared by

Douglas P. Boyle, Gregg Lamorey, Scott Bassett, Greg Pohll, and Jenny Chapman

submitted to

Nevada Site Office

National Nuclear Security Administration

U.S. Department of Energy

Las Vegas, Nevada

December 2005

Publication No. 45212 
Reference herein to any specific commercial product, process, or service by trade name, trademark, manufacturer, or otherwise, does not necessarily constitute or imply its endorsement, recommendation, or favoring by the United States Government or any agency thereof or its contractors or subcontractors.

Available for sale to the public, in paper, from:

U.S. Department of Commerce

National Technical Information Service

5285 Port Royal Rd. S/D

Springfield, VA 22161-0002

phone: 800.553.6847

fax: 703.605.6900

email: order@ntis.gov

online ordering: http://www.ntis.gov/ordering.htm

Available electronically at http://www.osti.gov/bridge

Available for a processing fee to the U.S. Department of Energy and its contractors, in paper, from:

U.S. Department of Energy

Office of Scientific and Technical Information

P.O. Box 62

Oak Ridge, TN 37831-0062

phone: 865.576.8401

fax: 865.576.5728

email: reports@adonis.osti.gov 


\title{
Development and Testing of a Groundwater Management Model for the Faultless Underground Nuclear Test, Central Nevada Test Area
}

\author{
Prepared by \\ Douglas P. Boyle, Gregg Lamorey, Scott Bassett, Greg Pohll, and Jenny Chapman \\ Division of Hydrologic Sciences \\ Desert Research Institute \\ Nevada System of Higher Education
}

Publication No. 45212

Submitted to

Nevada Site Office

National Nuclear Security Administration

U.S. Department of Energy

Las Vegas, Nevada

December 2005

The work upon which this report is based was supported by the U.S. Department of Energy under Contract \#DE-AC52-00NV13609. Approved for public release; further dissemination unlimited. 
THIS PAGE LEFT INTENTIONALLY BLANK 


\begin{abstract}
This document describes the development and application of a user-friendly and efficient groundwater management model of the Central Nevada Test Area (CNTA) and surrounding areas that will allow the U.S. Department of Energy and state personnel to evaluate the impact of future proposed scenarios. The management model consists of a simple hydrologic model within an interactive groundwater management framework. This framework is based on an object user interface that was developed by the U.S. Geological Survey and has been used by the Desert Research Institute researchers and others to couple disparate environmental resource models, manage the necessary temporal and spatial data, and evaluate model results for management decision making. This framework was modified and applied to the CNTA and surrounding Hot Creek Valley. The utility of the management model was demonstrated through the application of hypothetical future scenarios including mineral mining, regional expansion of agriculture, geothermal energy production, and export of water to large urban areas outside the region. While the results from some of the scenarios indicated potential impacts to the region near CNTA and others did not, together they demonstrate the usefulness of the management tool for managers who need to evaluate the impact proposed changes in groundwater use in or near CNTA may have on radionuclide migration.
\end{abstract}


THIS PAGE LEFT INTENTIONALLY BLANK 


\section{CONTENTS}

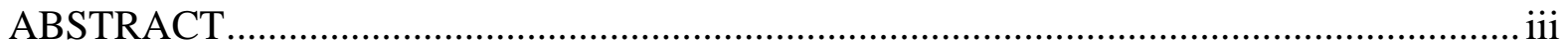

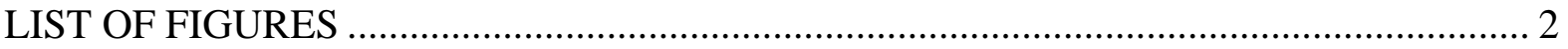

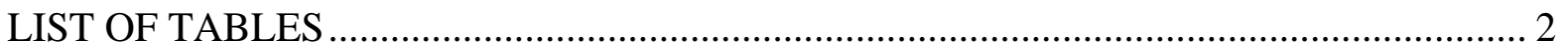

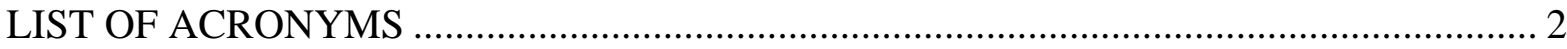

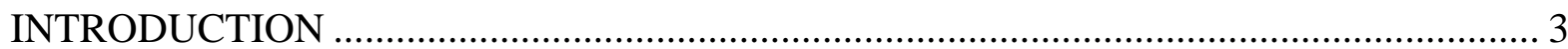

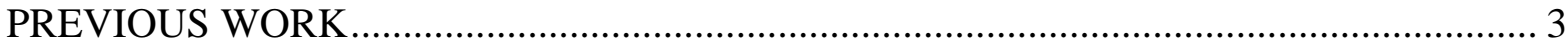

Hydrologic Models of the CNTA ................................................................................ 3

Tools for Management of Hydrologic Models ................................................................ 4

CNTA AND HOT CREEK VALLEY STUDY AREA …............................................ 4

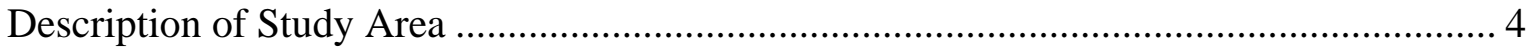

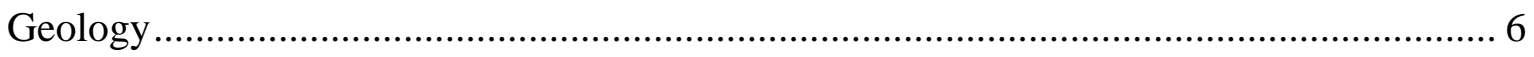

DEVELOPMENT OF THE CNTA MANAGEMENT MODEL ....................................... 7

Conceptual Groundwater Model............................................................................. 7

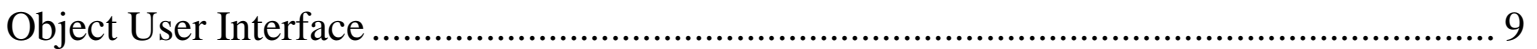

DEMONSTRATION OF CNTA MANAGEMENT MODEL UTILITY ............................ 14

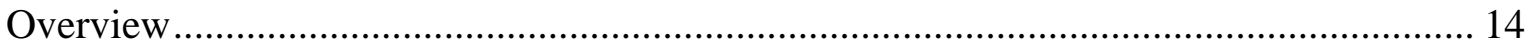

Development of Scenarios ....................................................................................... 15

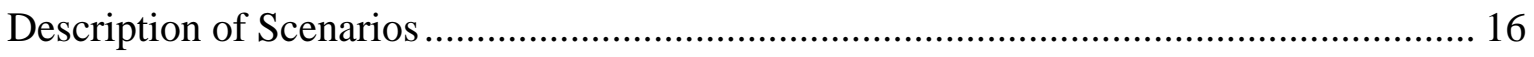

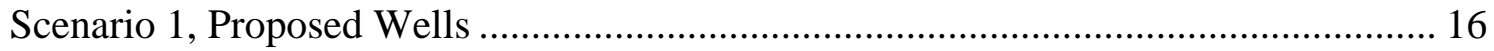

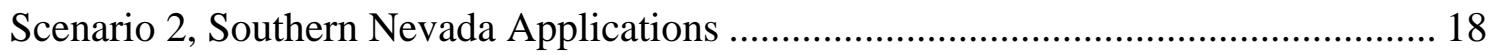

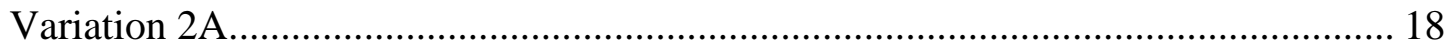

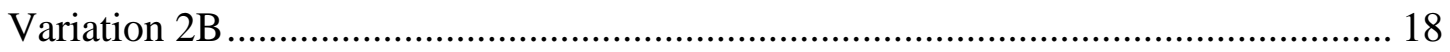

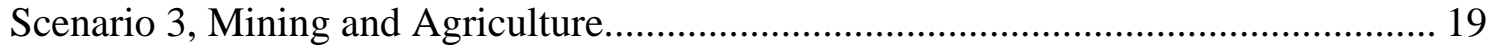

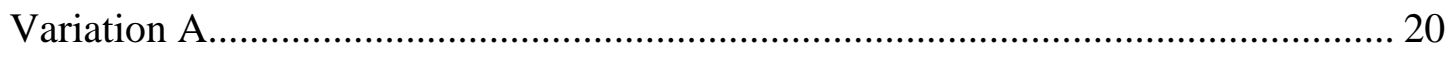

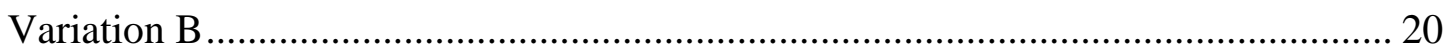

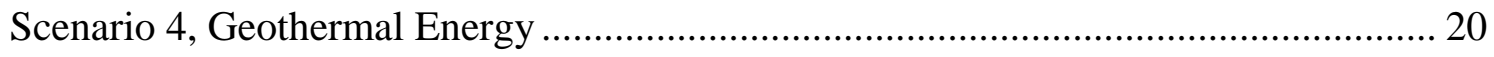

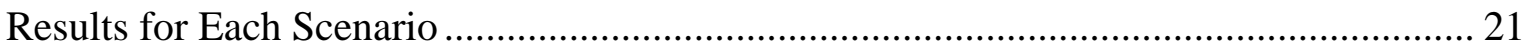

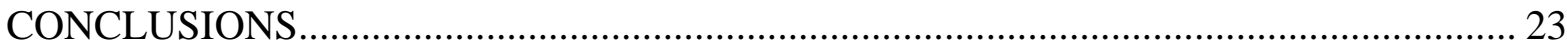

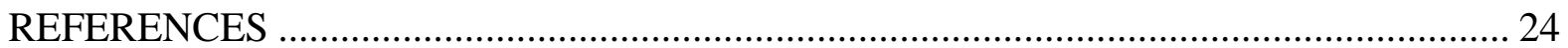




\section{LIST OF FIGURES}

1. Study area and model domain for Hot Creek Basin located in Nevada................................. 5

2. Groundwater model grid showing constant head boundaries and cross sections................... 7

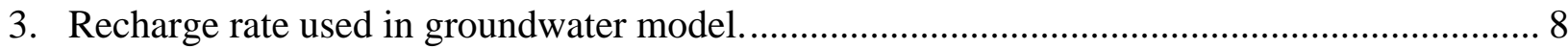

4. Heads at measurement locations (filled in circles) and modeled heads (colored grid) from

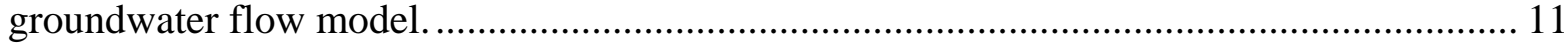

5. Hydraulic conductivities and modeled verses observed heads for groundwater flow model

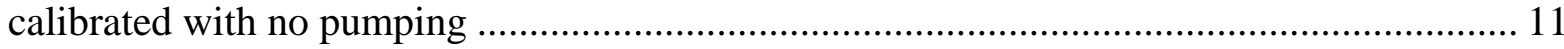

6. Head residuals (observed minus modeled head) for groundwater model............................ 12

7. OUI with the control panel on the left and the GIS panel on the right................................ 13

8. OUI showing the results of a model run where the drawdown has exceeded the threshold

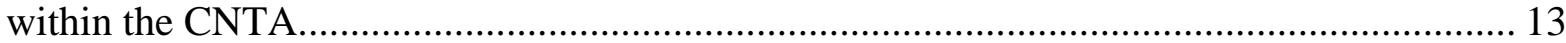

9. OUI well table for entering and examining pumping scenarios in a tabular format.............. 14

10. Distribution of wells for all scenarios..................................................................... 17

11. Total groundwater impacts presented for the trend in existing conditions .......................... 22

\section{LIST OF TABLES}

1. Locations of water level elevation and alluvium elevation measurements........................... 10

2. Filed agricultural water rights in Hot Creek Basin. ...................................................... 18

3. Proposed water rights for Scenario 2, Variation A.......................................................... 18

4. Proposed water rights for Scenario 2, Variation B....................................................... 19

5. Proposed water rights for Scenario 3, Variation A......................................................... 20

6. Proposed water rights for Scenario 3, Variation B. ........................................................ 20

7. Groundwater decrease and change from the trend in existing conditions. .......................... 23

$\begin{array}{ll}\text { CADD } & \text { Corrective Action Decision Document } \\ \text { CNTA } & \text { Central Nevada Test Area } \\ \text { DOE } & \text { U.S. Department of Energy } \\ \text { GMG } & \text { Geometric Multigrid Solver } \\ \text { LPF } & \text { Layer Property Flow } \\ \text { NTS } & \text { Nevada Test Site } \\ \text { OUI } & \text { object user interface } \\ \text { PEST } & \text { parameter estimation process } \\ \text { SNWA } & \text { Southern Nevada Water Authority } \\ \text { USGS } & \text { U.S. Geological Survey } \\ \text { XML } & \text { extensible markup language }\end{array}$




\section{INTRODUCTION}

The Central Nevada Test Area (CNTA), located between Tonopah and Ely, Nevada, contains one underground nuclear test. The test, named Faultless, was conducted in 1968 and resulted in creation of a cavity containing radionuclides centered at a depth of $975 \mathrm{~m}$. As part of a nationwide program of environmental restoration, and in accordance with a Federal Facility Agreement and Consent Order with the State of Nevada, the U.S. Department of Energy began a subsurface characterization effort in 1999. This culminated in development of a contaminant boundary within which radionuclides should remain for the next 1000 years. Groundwater systems are dynamic, however, and subject to change.

The U.S. Department of Energy (DOE) and state regulators need a flexible groundwater management tool that will allow them to evaluate the impact of any proposed changes (scenarios) in groundwater use in the nuclear test vicinity. Analysis and predictions of contaminant transport for the Corrective Action Decision Document (CADD), including the contaminant boundary, assume the continuation of current land and subsurface uses into the future. The groundwater flow and transport model developed for the CADD is not the most responsive tool to serve that function, and has additional limitations because the geographic scale of the model does not include the entire area of concern for water management. The primary aim of this project is to develop a user-friendly and efficient management model of the Central Nevada Test area (CNTA) and surrounding areas that will allow DOE and state personnel to evaluate the impact of future proposed scenarios.

The scope of the project involves the development of a simple groundwater flow model within an interactive groundwater management framework and demonstration of its utility through the application of several hypothetical future scenarios. While the hydrologic model was developed to reflect the general behavior of the complex CNTA flow and transport model, it is less intensive than the numerical flow and transport model developed for the CADD. The management model framework includes spatial and visualization tools to easily generate scenarios and analyze results. The hypothetical future scenarios developed to demonstrate the utility of the interactive groundwater management framework are intended to reflect a wide range of possible future situations that DOE and state personnel may need or want to evaluate in the CNTA and surrounding area. While some or all of these scenarios may never occur, together they provide a broad range of possible impacts that demonstrate the utility of the management tool for managers that need to evaluate the impact of proposed changes in groundwater use in or near CNTA (e.g., pumping wells) on the radionuclide migration (i.e., contaminant boundary).

\section{PREVIOUS WORK}

\section{Hydrologic Models of the CNTA}

A regional assessment of the water resources in the Hot Creek Valley area was conducted by Rush and Everett (1966). This assessment was used to determine the perennial yield of the valley used by the Nevada State Division of Water Planning. Several deep exploratory boreholes were drilled in Hot Creek Valley and vicinity as part of the Faultless test. Hydraulic testing of these boreholes is reported by Dinwiddie and Schroder (1971) including an interpretation of the groundwater flow system. They proposed two components of flow in the region: a shallow component in the upper $300 \mathrm{~m}$ and a deeper component 
inferred from hydraulic head data collected between 1,524 and 2,134 $\mathrm{m}$ below the surface. The shallow component flows from areas of recharge in the higher elevations in the west and north towards the south and southeast to areas of evapotranspiration down-valley. The deeper component flows to the northeast and east towards Railroad Valley.

More recently, two groundwater flow models containing the CNTA, at very different scales, have been reported. Prudic et al. (1995) present a regional groundwater flow model of the carbonate rock province of the Great Basin. This model encompasses $260,000 \mathrm{~km}^{2}$ covering much of Nevada and Utah. The model considers a shallow flow component moving from mountain ranges to adjacent valleys and a deeper component moving primarily in the carbonate rocks. In the Hot Creek Valley area, both flow components move to the south and east.

Pohlmann et al. (1999) present a stochastic groundwater flow and transport model for a 6.5 by $8 \mathrm{~km}$ area around the Faultless test site. Stochastic methods are used to generate hydraulic conductivity maps that are conditioned on the available conductivity measurements. The conductivities are divided into three hydrogeologic categories: alluvium, low-conductivity volcanic rocks, and high-conductivity volcanic rocks. Specified-head boundary conditions are assumed on the north, south, and bottom of the model with no-flow boundary conditions on the east and west. The head values used along the specified-head boundary result in surface flow to the south and deep flow to the north.

\section{Tools for Management of Hydrologic Models}

Researchers at the Desert Research Institute, in collaboration with the U.S. Geological Survey (USGS), have recently developed and implemented a computer application, Object User Interface (OUI), to provide the general framework needed to couple disparate environmental resource models and manage the necessary temporal and spatial data. The OUI is a map-based common interface for running computer hydrologic models, as well as acquiring, browsing, organizing, and selecting spatial and temporal data. The OUI is based in Java and Extensible Markup Language (XML) and will run on most computer operating systems (e.g., Windows, Solaris, MAC OS, etc.) without modification. The OUI is entirely an "open source" computer code that is available at no cost to the user. The Desert Research Institute and the USGS have recently developed and applied real-time OUI-based decision support tools for water managers (e.g., U.S. Bureau of Reclamation, U.S. Army Corps of Engineers, U.S. Natural Resource Conservation Service) in several large watershed systems in the western United States (e.g., Rio Grande, Gunnison River, Yakima River, Carson-Truckee river systems, among others). Several of these systems included representation of groundwater-surface water interactions within the watershed systems that are critical to decision making and scenario analysis for water resource management. The OUI-based software was modified in this project to implement an OUI-based groundwater management tool for DOE and state water managers of the CADD.

\section{CNTA AND HOT CREEK VALLEY STUDY AREA}

\section{Description of Study Area}

The CNTA, located in Hot Creek Valley about $95 \mathrm{~km}$ northeast of Tonopah and $175 \mathrm{~km}$ southwest of Ely, was the site of the Faultless nuclear test (see Figure 1). The test 
was conducted on January 19, 1968, at a depth of $975 \mathrm{~m}$ within a 0.66-m-diameter casing in volcanic sediments overlain by alluvium. The test consisted of a $200-$ to 1,000-kt yield nuclear detonation to assess the usefulness of the site for higher-yield tests.

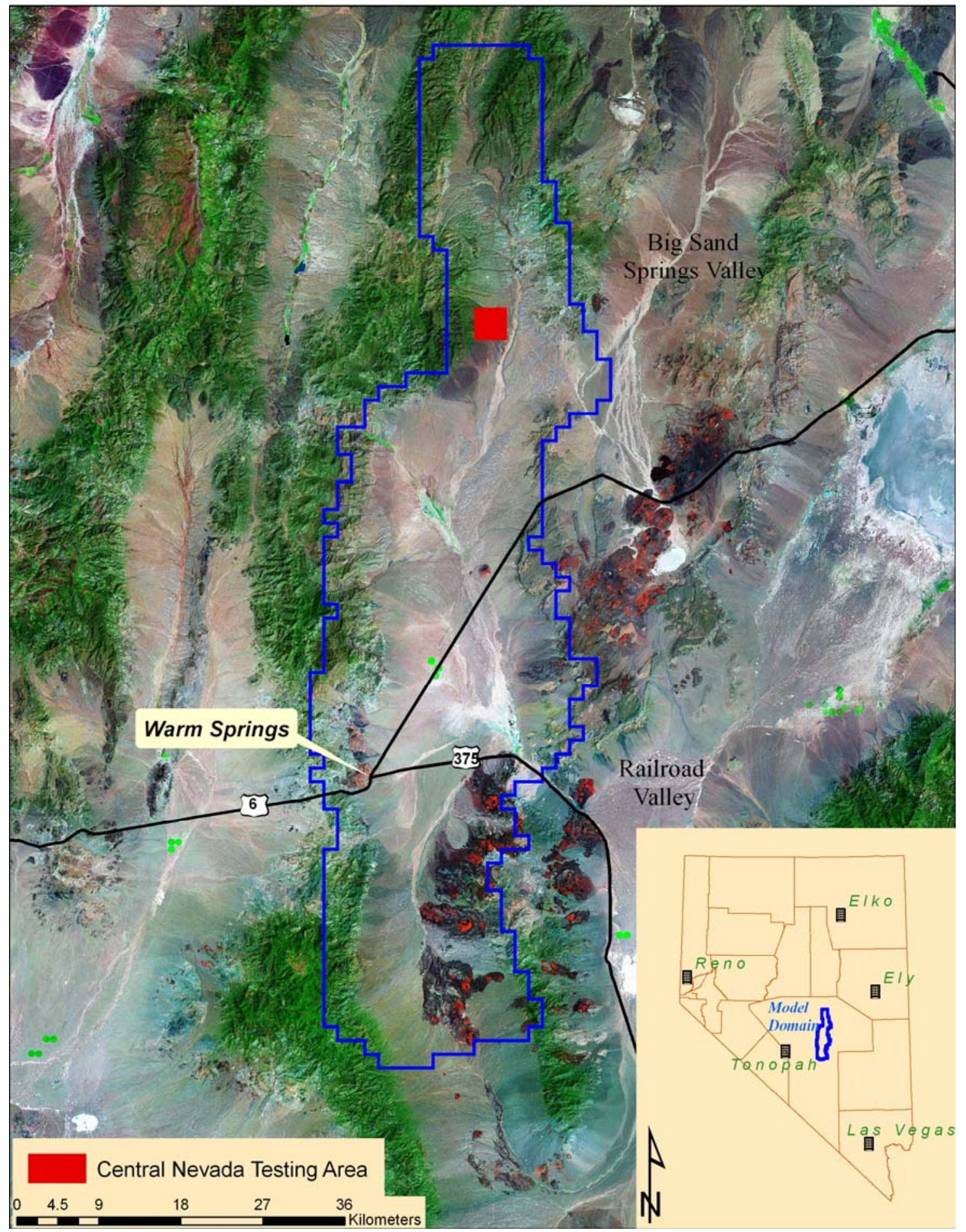

Figure 1. Study area and model domain for Hot Creek Basin located in Nevada. 
Hot Creek Valley is located in south-central Nevada in the Basin and Range province. The valley trends north-south and is about $110 \mathrm{~km}$ long and up to $30 \mathrm{~km}$ wide. Elevations range from 1,580 $\mathrm{m}$ on the valley floor to 3,111 $\mathrm{m}$ at Morey Peak in the Hot Creek Range to the northwest. The Faultless site is in the northern part of the valley on an alluvial fan with a surface elevation of 1,860 m. Hot Creek Valley drains to the southeast toward Railroad Valley with significant streamflow only during periods of large runoff from mountain streams.

The climate is semi-arid with less than $25 \mathrm{~cm} /$ year precipitation in most of the valley. Large diurnal and seasonal temperature changes, typical for the high desert, are experienced throughout the valley. At the Blue Jay weather station, on Highway 6 in Hot Creek Valley, the January average maximum temperature is $7.2^{\circ} \mathrm{C}$ and average minimum temperature is $-10.6^{\circ} \mathrm{C}$, while the July average maximum temperature is $34.4^{\circ} \mathrm{C}$ and average minimum temperature is $10.2^{\circ} \mathrm{C}$. Sagebrush dominates the valley floor with pinyon pine and juniper at the higher elevations.

\section{Geology}

Hot Creek Valley is a long graben oriented north-south containing a thick sequence of Quaternary and Tertiary fill up to 1,200 m thick underlain by Tertiary volcanics. The ranges bounding the valley are comprised of Tertiary volcanics, principally tuffs and rhyolite lavas, overlying Paleozoic carbonates. North-south-trending high-angle faults define the contact between the valley and the bounding ranges. The Tertiary volcanics are highly faulted, containing normal, thrust, and strike-slip faults. Paleozoic rocks exposed in the Hot Creek Range are Cambrian to Permian in age and are complexly folded and faulted. The Faultless site is within the Morey Peak-Hot Creek Caldera complex and the Pancake Range Calderas are to the south (Ekren et al., 1973).

The alluvium contains pebble- to boulder-sized fragments of welded tuff and rare Paleozoic rocks, enclosed in a clay cemented matrix of sand-sized crystal grains, particles of welded tuff, and some Paleozoic chert, siltstone, and carbonate fragments. The upper 150 to $300 \mathrm{~m}$ is generally unconsolidated, with induration increasing with depth. Volcanism was active during the early deposition of the alluvium, indicated by interbedding of the older alluvium with undisturbed tuffs and tuffaceous sediments (Hoover, 1968).

The Tertiary tuffaceous sediments include consolidated clastics derived from surrounding Tertiary volcanics and Paleozoic sediments. The tuffaceous sediments are more indurated than the alluvium, a result of zeolitization of volcanic glass and a larger amount of clay matrix material. Thin intervals of nonwelded zeolitized tuff, densely welded tuff, reworked ash-fall, and tuffaceous sandstones and siltstones are present within the tuffaceous sediments. The sediments display evidence of only minor reworking, short transportation, and possible active volcanism during deposition.

The Tertiary volcanics consist of tuffs, tuffaceous sediments, sandstones, basalts, and rhyolite lavas ranging in age from Oligocene to Pliocene (Ekren et al., 1973). The tuffs are generally fine grained and tightly welded, containing numerous fractures and normal, thrust, and strike-slip faults. 


\section{DEVELOPMENT OF THE CNTA MANAGEMENT MODEL}

\section{Conceptual Groundwater Model}

A groundwater flow model of the Hot Creek Valley was constructed to assess the impact of various pumping scenarios on the hydraulic heads in the CNTA, site of the Faultless test. The groundwater model domain extends approximately $112 \mathrm{~km}$ north to south and up to $32 \mathrm{~km}$ east to west (see Figure 2). Only the flow in the alluvium is modeled because this is where existing pumping occurs and is also the likely horizon for any proposed future pumping. The model grid consists of three vertical layers with a horizontal grid spacing of $1.5 \mathrm{~km}$. The groundwater flow is generally from areas of recharge in the north and west to Railroad Valley located to the southeast of Hot Creek Valley.

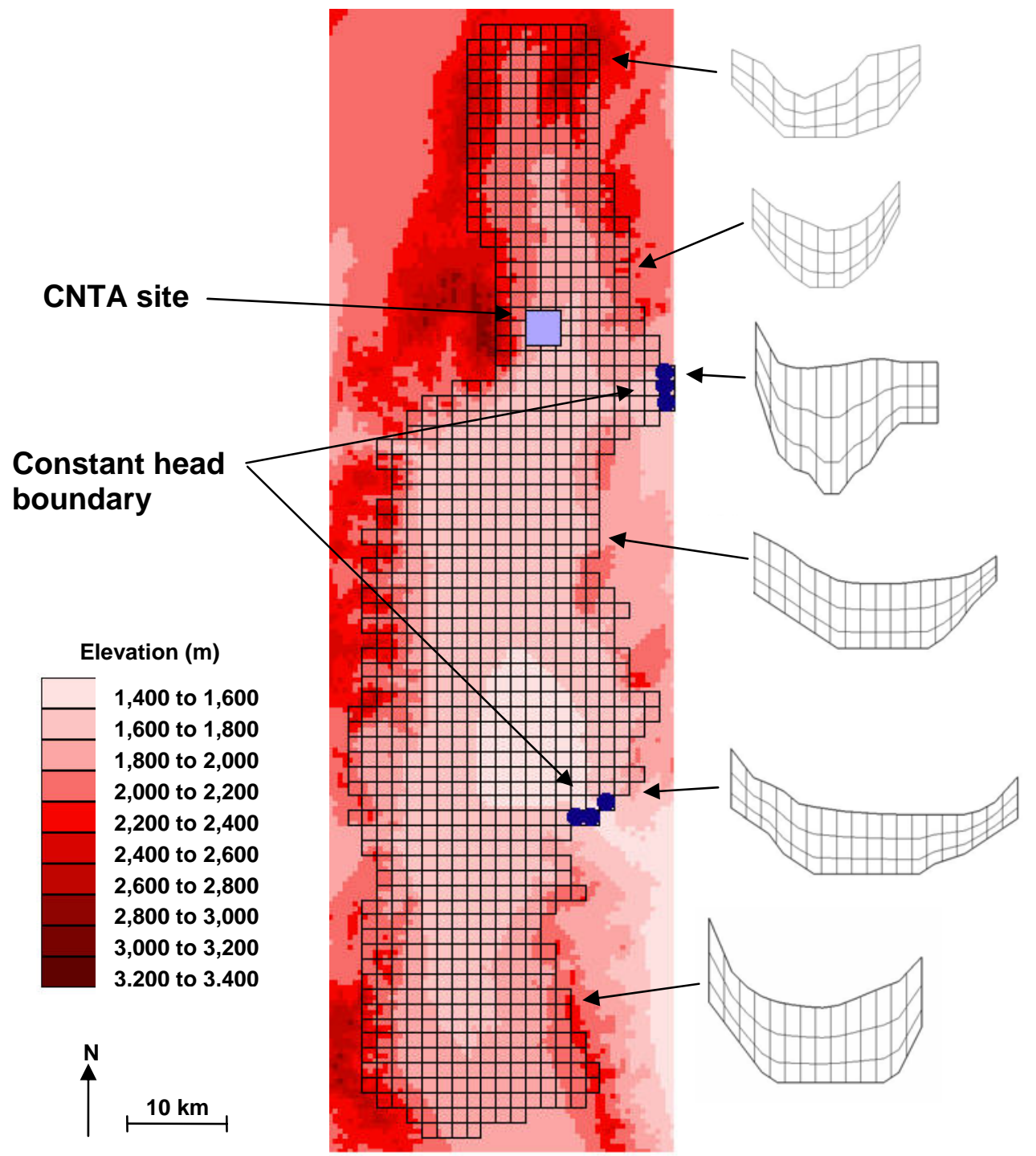

Figure 2. Groundwater model grid showing constant head boundaries and cross sections. 
The model was implemented using MODFLOW 2000 (Harbaugh et al., 2000) with the Layer Property Flow (LPF) module to describe the model geometry and the Geometric Multigrid Solver (GMG) module to solve the system of finite difference equations for the flow model. The parameter estimation process (PEST) was used to estimate hydraulic conductivity values.

In this application of MODFLOW to the Hot Creek Valley, it was assumed that there are no-flow groundwater boundaries around the valley with the exception of constant head boundaries where flow enters Railroad Valley in the southeast and at a saddle in the northeast, where groundwater flow can enter Big Sand Springs Valley (Figures 1 and 2). Recharge to the groundwater model, shown in Figure 3, was estimated using PRISM (Parameter-elevation Regressions on Independent Slopes Model) (Daly et al., 1997). Precipitation is converted to recharge using a method described by Epstein (2004) and scaled to equal the perennial yield of $18,590 \mathrm{~m}^{3} /$ day as prescribed by the Nevada State Division of Water Planning (http://water.nv.gov/Water\%20planning/wat-fact/gwinfo.htm).

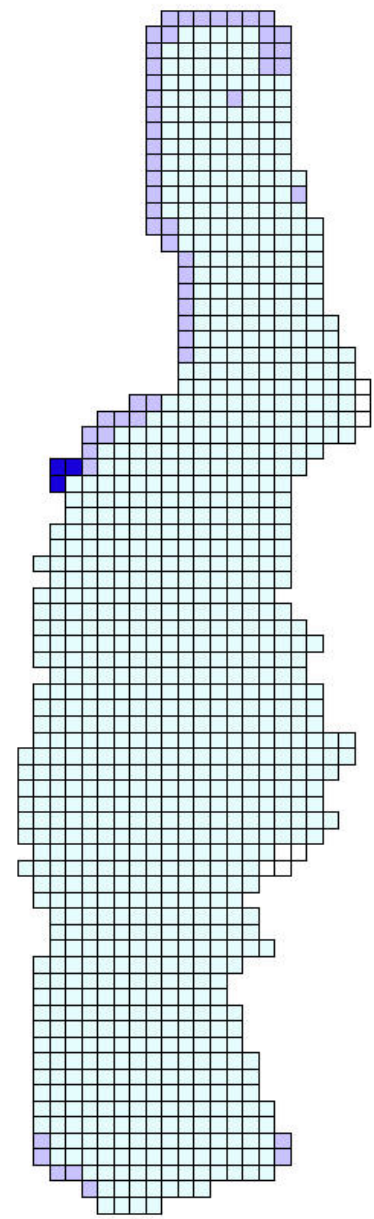

Recharge m/yr)

Figure 3. Recharge rate used in groundwater model.

Several wells in the valley have been used to establish depth to water and the thickness of the alluvium (Table 1 and Figure 4). Several deep exploratory boreholes were drilled prior to the Faultless test to help characterize the area (Dinwiddie and Schroder, 
1971). Hydraulic conductivities of the alluvium were measured in some of the exploratory boreholes using straddle packer tests and a pumping test. The straddle packer tests yielded hydraulic conductivities between 3.6E-1 and 6.2E-5 m/day with a strong trend of decreasing values with depth. The pumping test yielded a hydraulic conductivity of $0.56 \mathrm{~m} /$ day.

The model domain has been divided into three hydraulic conductivity zones. In the northern portion of the model, all three layers are grouped into one zone. In the remainder of the model, the top layer is designated as a separate zone from the middle and lower layers. This configuration of the model domain was selected from a variety of different hydraulic conductivity zones that were investigated based on model stability and through comparisons with historic head values.

Since most of the observed head measurements were acquired prior to 1970 and predate the majority of the known pumping activities in the valley, the model was calibrated in a steady-state mode with no pumping by adjusting the hydraulic conductivity values in each of the three zones to match the observed head values. The resulting hydraulic conductivity values and modeled verses observed heads are shown in Figure 5.

Figure 4 shows a map of the modeled heads along with the measured heads. Head residuals, calculated as the observed head minus the modeled head, are shown in Figure 6. The root-mean-squared-error of the modeled and observed heads is $14 \mathrm{~m}$. When divided by the range of head values in the model (1,540 $\mathrm{m}$ to 2,247 $\mathrm{m}$ ), this yields a relative error of 2 percent. These results are consistent with the head levels and hydraulic conductivity values for the alluvium reported by Pohlmann et al. (1999).

\section{Object User Interface}

The object user interface (OUI) is a map-based framework for models and modeling data developed and maintained by the USGS (www.brr.cr.usgs.gov/projects/ SW_precip_runoff/mms). The OUI provides a common interface for running models, as well as acquiring, browsing, organizing, displaying, and selecting spatial and temporal data. The OUI is highly configurable through the use of a user-modifiable, text-based, control file that is written in the eXtensible Markup Language (XML).

The OUI is displayed on a computer screen as a control panel and a GIS panel (Figure 7). Themes consisting of spatial information such as elevation, roads, and model grids can be activated on the GIS panel from the control panel. The control panel also allows information to be entered for model setup, control of model execution, and viewing of model results. Model results can be viewed as themes or animations of state variables such as hydraulic heads and drawdown.

Enhancements to the OUI for this project include enabling the OUI to run MODFLOW and developing of a tool for entering pumping scenarios. Linking the OUI to MODFLOW required the modification of the OUI Java and XML code to write and read MODFLOW files and execute the MODLOW computer application. For example, information describing a MODFLOW well (location, pumping rate, etc.) is entered and displayed using the OUI and then written to a MODFLOW well file format prior to executing MODFLOW. MODFLOW output results, such as drawdown, are read by the OUI after a MODFLOW model run (made from the OUI) and displayed in the OUI. 
Table 1. Locations of water level elevation and alluvium elevation measurements.

\begin{tabular}{|c|c|c|c|c|}
\hline Name & $\begin{array}{l}\text { X_coord } \\
\text { (UTM) }\end{array}$ & $\begin{array}{l}\text { Y_coord } \\
\text { (UTM) }\end{array}$ & $\begin{array}{l}\text { Water Level Elevation } \\
(\mathrm{m})\end{array}$ & $\begin{array}{l}\text { Alluvium Elevation } \\
\text { (m) }\end{array}$ \\
\hline HTH-1 & 568543 & 4275398 & $1,668.1$ & $1,103.5$ \\
\hline HTH-2 & 568502 & 4275546 & $1,666.4$ & \\
\hline HTH-21-1 & 580377 & 4271116 & $1,637.6$ & \\
\hline НTH-3 & 576919 & 4267658 & $1,633.5$ & $1,754.2$ \\
\hline HTH-5 & 567436 & 4262286 & & $1,301.9$ \\
\hline UC-1-I-1 & 568290 & 4276257 & & $1,127.8$ \\
\hline UC-1-I-2 & 568274 & 4276274 & & $1,403.3$ \\
\hline UC-1P2SR & 568315 & 4276368 & $1,659.9$ & \\
\hline UCe-11 & 567566 & 4272320 & & 762.9 \\
\hline UCe-12A & 557732 & 4306908 & & $1,641.4$ \\
\hline UCe-17 & 568050 & 4281241 & & $1,354.9$ \\
\hline UCe-18 & 570424 & 4270953 & $1,656.5$ & \\
\hline UCe-20 & 568061 & 4271871 & $1,651.3$ & \\
\hline UCe-9 & 547938 & 4295598 & & $1,233.5$ \\
\hline 9_mile_rch & 561766 & 4256650 & $1,632.2$ & \\
\hline EW_Fallini & 569250 & 4231434 & $1,566.8$ & \\
\hline Fallini_rch & 573082 & 4228229 & $1,557.7$ & \\
\hline Mx_obs_375 & 566870 & 4228710 & $1,568.4$ & \\
\hline MX_obs_tybo & 561923 & 4241012 & $1,569.7$ & \\
\hline MX_obs_valley & 564411 & 4248337 & $1,595.9$ & \\
\hline MX_well_north & 566555 & 4260489 & $1,634.8$ & \\
\hline MX_well_rev & 558587 & 4217969 & $1,574.4$ & \\
\hline MX_well_tybo & 558893 & 4244722 & $1,595.4$ & \\
\hline NDOT_maint & 567709 & 4247167 & $1,587.9$ & \\
\hline North_art_well & 570400 & 4288259 & $1,882.5$ & \\
\hline North_well & 569086 & 4290266 & $1,913.9$ & \\
\hline Twin_Springs & 569237 & 4240610 & $1,570.2$ & \\
\hline Tybo_well & 560406 & 4243521 & $1,572.1$ & \\
\hline 3N50E13M & 558327 & 4217934 & $1,579.8$ & \\
\hline 3N51E18M & 559922 & 4217946 & $1,590.7$ & \\
\hline 4N50E22-MX & 558112 & 4227268 & $1,570.9$ & \\
\hline 4N51E29M & 565166 & 4225543 & $1,586.0$ & \\
\hline 4N51E3M & 568300 & 4231971 & $1,583.1$ & \\
\hline 4N51E5M & 565114 & 4231945 & 1,583.1 & \\
\hline 4N52E6-MX & 572591 & 4232224 & $1,566.1$ & \\
\hline 5N50E13M & 561871 & 4238333 & $1,580.1$ & \\
\hline 5N50E1M & 561846 & 4241540 & $1,556.2$ & \\
\hline 5N51E19M & 563484 & 4236736 & $1,530.0$ & \\
\hline 5N55E33 & 569010 & 4233025 & $1,553.5$ & \\
\hline 5N55E34 & 567549 & 4233259 & $1,547.6$ & \\
\hline 5N55E35 & 566090 & 4233340 & $1,556.0$ & \\
\hline 5N55E36D1 & 564049 & 4233200 & $1,560.2$ & \\
\hline 5N55E36D2 & 563926 & 4233384 & $1,560.5$ & \\
\hline 6N50E10 & 557583 & 4250197 & $1,619.4$ & \\
\hline 6N50E27M & 558537 & 4244589 & $1,598.0$ & \\
\hline 6N51E22M & 568267 & 4246285 & $1,598.3$ & \\
\hline 7N51E10M & 568157 & 4259223 & $1,635.9$ & \\
\hline 8N50E33M & 556786 & 4262364 & $1,661.3$ & \\
\hline 8N51E34M & 568129 & 4262452 & $1,648.1$ & \\
\hline 12N51E15M & 566551 & 4303077 & $2,147.5$ & \\
\hline
\end{tabular}




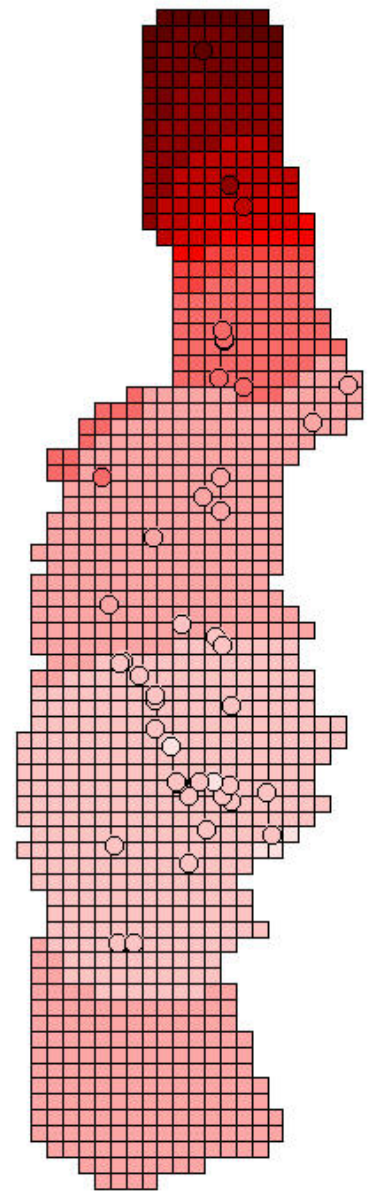

\section{Heads (m)}

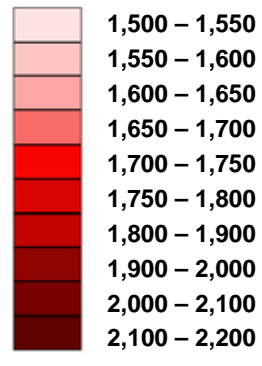

Figure 4. Heads at measurement locations (circles) and modeled heads (colored grid) from groundwater flow model.

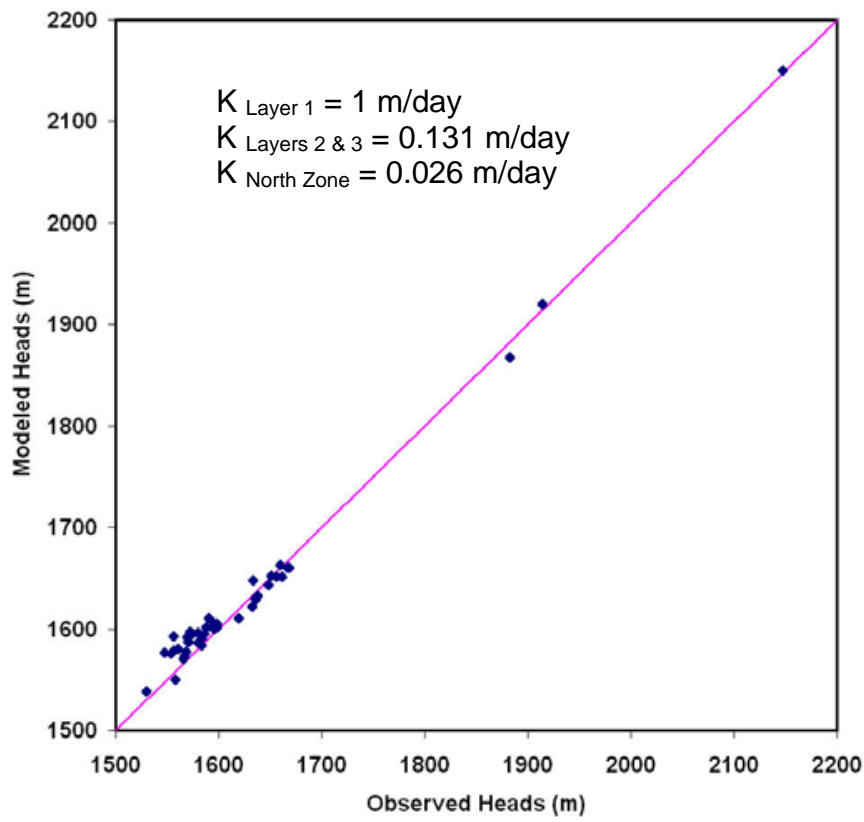

Figure 5. Hydraulic conductivities and modeled verses observed heads for groundwater flow model calibrated with no pumping. 
One objective of this project was to build a tool within the OUI that will allow a user to examine different future pumping scenarios in terms of the head drawdown exceeding a threshold within the CNTA boundary. To facilitate this, a dialog box was created that informs the user at the end of a MODFLOW run if a pre-selected threshold value of drawdown has been exceeded at CNTA site. If the model results indicate that the drawdown within CNTA exceeds this threshold, a message box is presented to the user with this information (Figure 8).

The OUI tool developed for entering information about pumping scenarios can be used in two modes: point and click, and tabular entry (Figure 9). Point-and-click entry entails clicking the mouse on the appropriate model grid location; a dialog box is then activated for entry of the pumping rate. Tabular entry entails entering $\mathrm{x}$ and $\mathrm{y}$ coordinates and the corresponding pumping rate. Once the information is entered, each scenario can be saved to a file for future use.
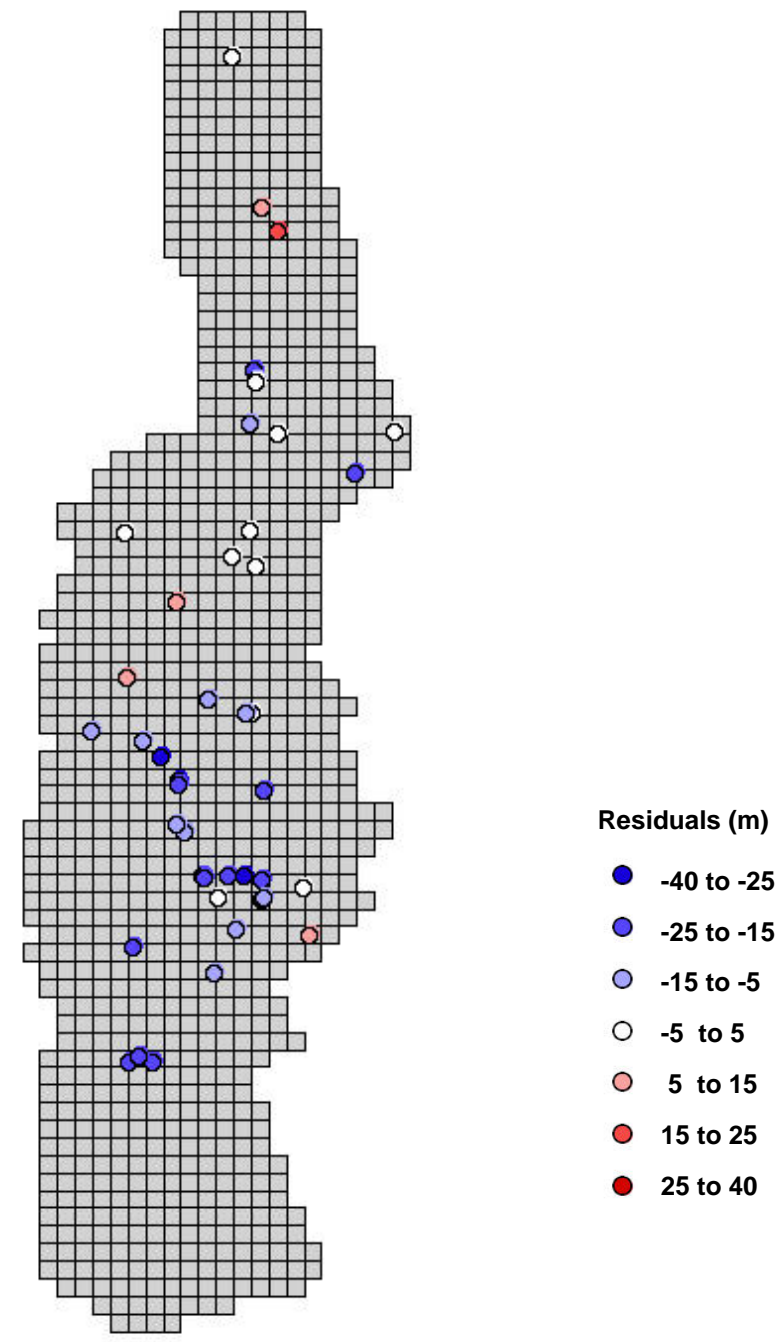

Figure 6. Head residuals (observed minus modeled head) for groundwater model. 


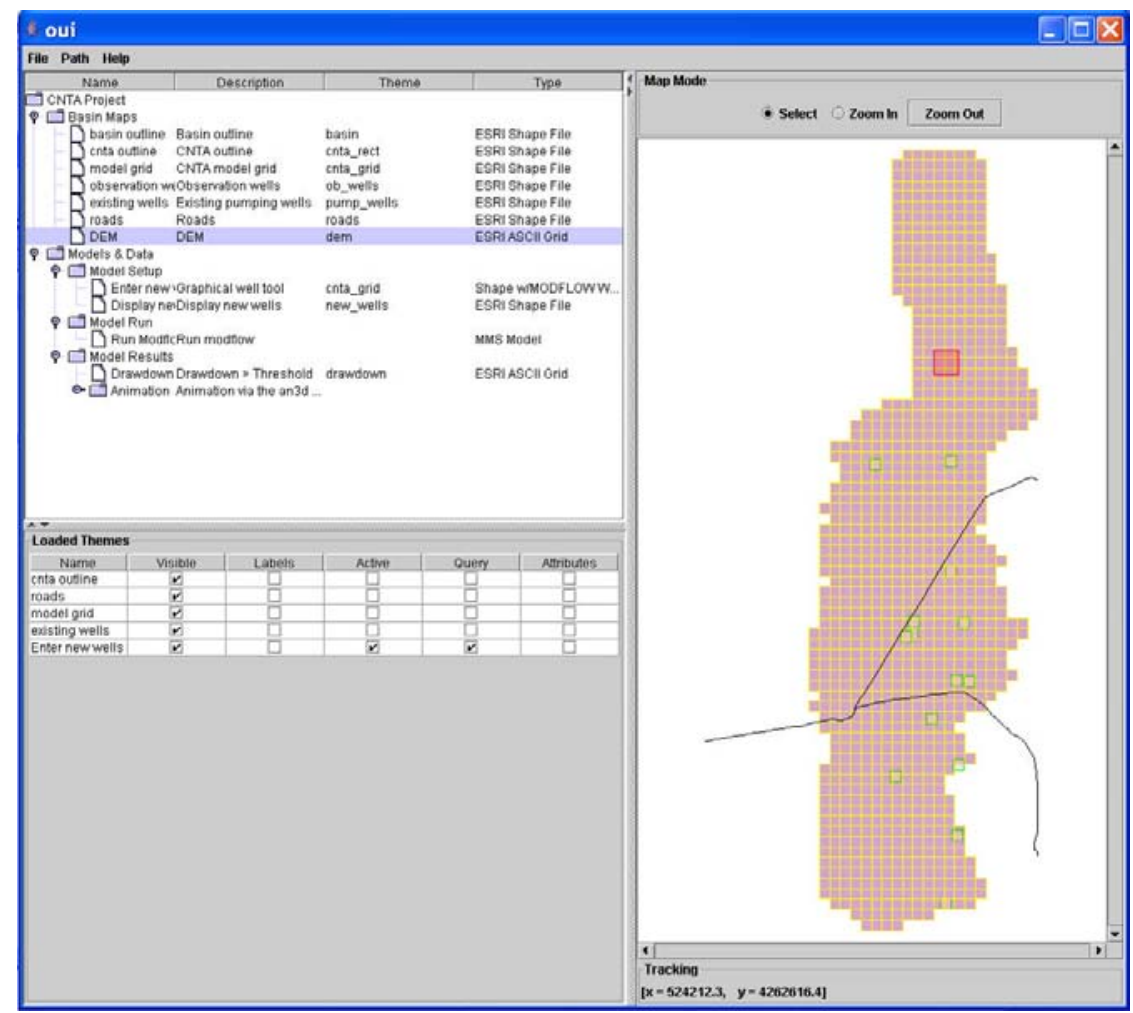

Figure 7. OUI interface with the control panel and the left and the GIS panel on the right.

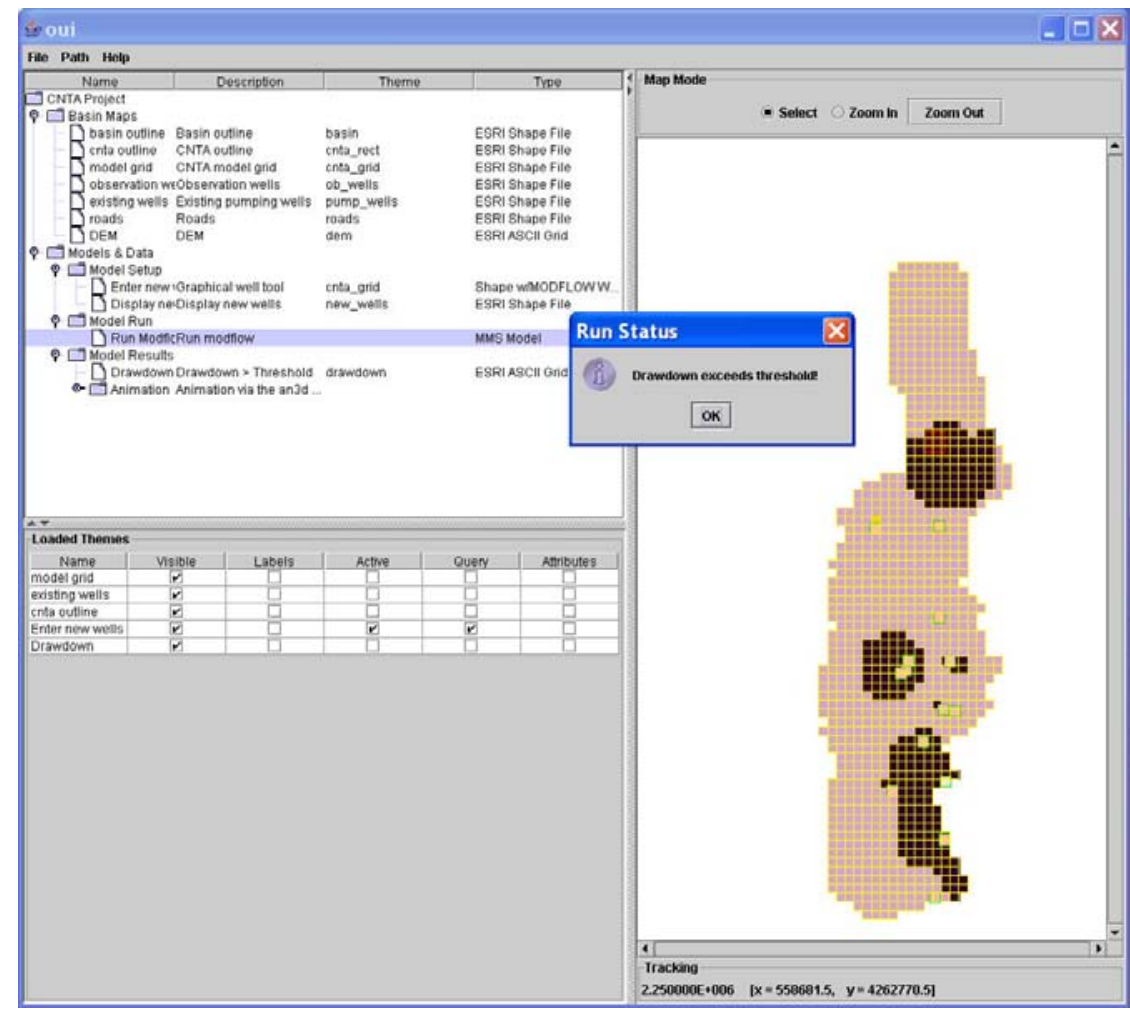

Figure 8. OUI interface showing the results of a model run where the drawdown has exceeded the threshold within the CNTA. 


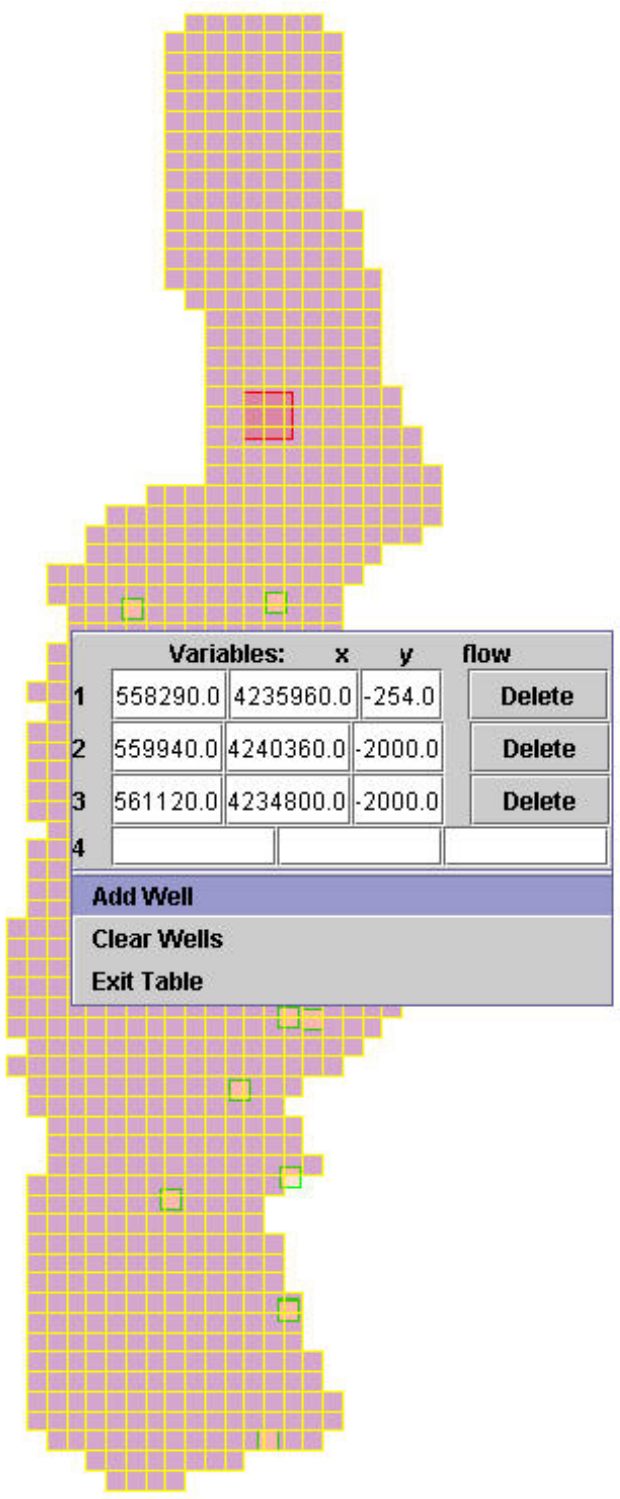

Figure 9. OUI well table for entering and examining pumping scenarios in a tabular format.

\section{DEMONSTRATION OF CNTA MANAGEMENT MODEL UTILITY}

\section{Overview}

The purpose of the CNTA management model is to determine the potential for future groundwater withdrawals to alter the groundwater flow system adjacent to the CNTA. Although the groundwater flow model used within the management model does not simulate radionuclide transport or flow within the volcanic units, it provides an indication of the potential changes due to increased pumping activities. The site-scale flow and transport model that was used to calculate the contaminant boundary assumed that the groundwater will remain in steady-state or equilibrium conditions. Therefore, if pumping rates increase within the Hot Creek Valley, it is possible that the water levels and associated flow directions 
may change in the vicinity of the CNTA. This management model will highlight changes that would potentially intersect the CNTA such that the high-resolution flow and transport model can be updated to reflect the new conditions at the site.

Declining water levels (drawdown) is the metric used to determine potential changes in the groundwater system near the CNTA. The OUI has the capability of presenting numerical values of drawdown, but the user may be most interested in significant water level declines that intersect the CNTA. All scenarios presented in this report use a drawdown threshold of $1 \mathrm{~m}$ to show how increased pumping influences the spatial changes in the groundwater system. The user also has the capability of changing the drawdown threshold within the OUI.

Declining water levels near the CNTA have two potential consequences for radionuclide transport within the volcanic aquifer. As water levels decline in the alluvium, both horizontal and vertical hydraulic head gradients may change within the volcanic unit in which radionuclide transport occurs. Strong upward vertical gradients from the volcanics to the alluvium may develop, which would increase the likelihood of radionuclides moving upward into the more permeable alluvial sediments. Another possibility is a change in horizontal direction of flow within the volcanic aquifer. In either case, one needs to revisit the high-resolution model to determine how radionuclide transport and the associated contaminant boundary may change in response to these conditions.

In the following sections, the details and results of several hypothetical future scenarios are described. The scenarios were developed to demonstrate the utility of the interactive groundwater management framework and are intended to reflect a wide range of possible future situations that DOE and state personnel may need or want to evaluate in the CNTA and surrounding area. While some or all of these scenarios may never occur, together they provide a broad range of possible impacts that demonstrate the utility of the management tool for managers who need to evaluate the impact of proposed changes in groundwater use in or near the CNTA (e.g., pumping wells) on the radionuclide migration (i.e., contaminant boundary). For each scenario, the calibrated MODFLOW model was run in a transient mode for a 100-year period.

\section{Development of Scenarios}

For the purpose of demonstrating the utility of the CNTA groundwater management tool, a few general scenarios were developed using scenario theory. Scenario creation for any region is driven by the single overlying question of how might a region change (Shearer et al., in press) given a specific change in the existing system. Properly framing this question drives any scenario-based study. In general, change within a region is influenced by a host of factors including technological, economic, social, political, and environmental concerns. Many of these factors act together to form change within a region and the specifics associated with the factors are formulated within a range of uncertainties. The range of uncertainties along with driving factors allow for the formulation of focal issues that are likely to instigate change. These focal issues are often influenced by driving factors that may specifically operate within the region or may be contained within macro-scale (outside the region) forces (Schwartz, 1996). 
In this project, the primary focal issue for this region is how do potential changes in land use impact groundwater supply. Based on a site visit and discussions with both residents and nonresidents familiar with the area, four key uncertainties involving land-use change implications emerged. They are:

1. Will mineral mining increase in the region?

2. Is regional expansion of agriculture going to occur?

3. Will geothermal energy production occur near Hot Creek?

4. Will demands for water in large urban centers outside the region result in water demand within the region?

These four key uncertainties were translated into four potential scenarios with variations within two of the scenarios (total of six scenarios). All the scenarios assume the current water rights are fulfilled by allowing pumping to occur at the designated duty of each water right. Each of the potential scenarios was selected based on what is perceived as different uses, which are likely to exist in conflict if they occur together. This note being made, the tool is capable of combining aspects, and subsequently well pumping rates, from any of the scenarios into a single outcome. The four scenarios and two variations are:

- Scenario 1, Proposed Wells

- Scenario 2A, Southern Nevada Applications-Full Pumping

- Scenario 2B, Southern Nevada Applications-Perennial Yield

- Scenario 3A, Mining and Agriculture-Full Pumping

- Scenario 3B, Mining and Agriculture-Perennial Yield

- Scenario 4, Geothermal Energy

While some or all of these scenarios may never occur, together they provide a broad range of possible impacts that demonstrate the utility of the management tool for managers that need to evaluate the impact of proposed changes in groundwater use in or near CNTA (e.g., pumping wells) on the radionuclide migration (i.e., contaminant boundary). The variations in two of the scenarios (Scenario 2B and 3B) are designed to show how modifications can be made to fit state engineer groundwater perennial yield forecasts. The suite of scenarios is designed to show an adequate range of the possible policy and land-use decisions that may occur in the future. Figure 10 shows the existing pumping wells and possible distribution of new wells by scenario and should be used as a spatial reference for understanding the scenario descriptions that follow.

\section{Description of Scenarios}

\section{Scenario 1, Proposed Wells}

The remote location of the Hot Creek Basin yields very little change in land use for the region. The existing 17 water rights continue pumping at their current rates, with the only change being approval of already filed agricultural water rights in the basin. These water rights are detailed in Table 2. The Nevada State Engineer's office currently identifies these water rights as "ready for action.” This implies that the water rights applications are acknowledged by the State Engineer's office, but they are not approved due to outstanding issues. Water rights with the "ready for action" designation were filed under either the Desert Land Act's desert-land entry or the Carey Land Act and therefore require public land negotiation prior to their approval. The applicants successfully negotiate between the U.S. 
Bureau of Land Management, the Nevada State Public Lands office, and the State Engineer's office to certify their water rights, allowing them to pump their water. For applicants who filed for irrigation rights, annual duties were calculated by assuming the pumping will only occur for a third of the year, or the effective irrigation season.

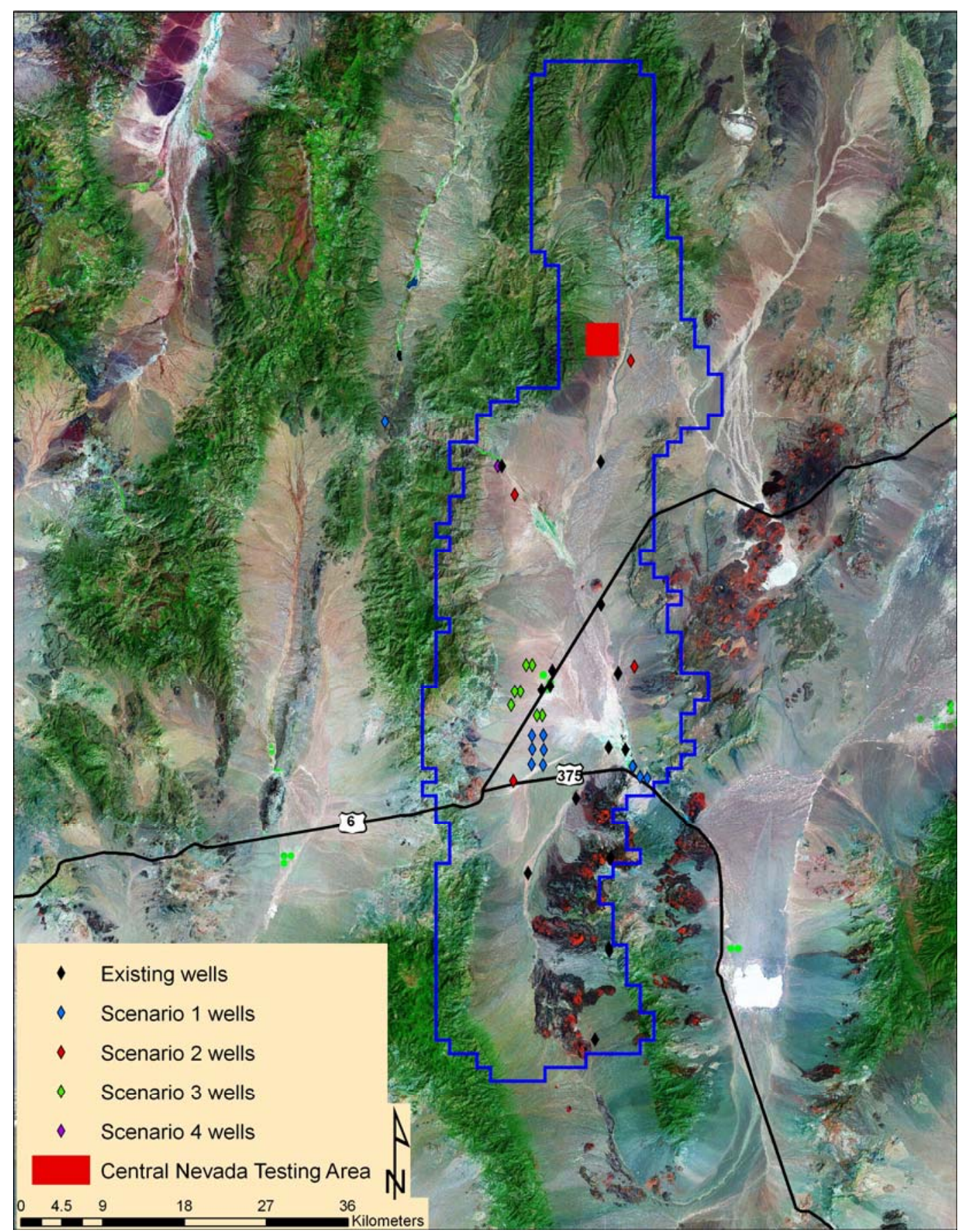

Figure 10. Distribution of wells for all scenarios including existing pumping wells. 
Table 2. Filed agricultural water rights in Hot Creek Basin.

\begin{tabular}{lccccl}
\hline \multicolumn{1}{c}{ Owner } & Rights & Date & $\begin{array}{c}\text { Irrigated } \\
\text { Hectares }\end{array}$ & $\begin{array}{c}\text { Annual Duty } \\
\left(\mathrm{m}^{3} / \mathrm{day}\right)\end{array}$ & Notes \\
\hline $\begin{array}{l}\text { Great Basin Land } \\
\begin{array}{l}\text { Company, Inc. } \\
\text { Great Basin Land }\end{array}\end{array}$ & 4 & $5 / 4 / 1977$ & 1,036 & 35,692 & \\
Company, Inc. & 2 & $5 / 4 / 1977$ & 518 & 17,846 & $\begin{array}{l}\text { Undefined annual duty, } \\
\text { amount quantified from } \\
\text { diversion rate }\end{array}$ \\
Fallini, Joe B., Jr. & 4 & $\begin{array}{c}7 / 29 / 1977 \text { to } \\
4 / 2 / 1992\end{array}$ & 235 & $8,708.47$ & $\begin{array}{l}\text { Includes one stock } \\
\text { diversion }\end{array}$ \\
Fallini, Helen & 1 & $8 / 6 / 1979$ & 259 & 4,848 & Stock diversion \\
Colvin and Son, LLC & 1 & $7 / 17 / 2001$ & NA & 0.1 & \\
\hline
\end{tabular}

\section{Scenario 2, Southern Nevada Applications}

This scenario considers the population growth that has recently characterized Nevada. The population centers of the state continue to grow at their current rates, creating a need to acquire more in-state water resources. Las Vegas in particular, through the Southern Nevada Water Authority (SNWA), continues to look to rural Nevada and expands its currently proposed groundwater applications to include the Hot Creek Basin. Up to four wells are drilled in the basin that pump water through a pipeline down to Las Vegas. These wells utilize a pipeline that was created for transporting the large amount of groundwater resources the SNWA already leases throughout the area. Similar to these other groundwater rights, the wells are pumped for a 100-year lease period. After their lease of the water has expired, the impacts of pumping are reassessed and local water needs are evaluated.

\section{Variation $2 A$}

The SNWA wells are pumped at two different levels, similar to wells already applied for in adjacent basins. Two wells in the northern part of the basin are pumped to yield $14,683 \mathrm{~m}^{3}$ /day per well. Two wells in the southern part of the basin are pumped to yield $24,471 \mathrm{~m}^{3} /$ day per well. These wells combined pump 78,308 $\mathrm{m}^{3} /$ day (see Table 3). This is more water than the Nevada State Engineer has deemed as the perennial yield, therefore this scenario would mine groundwater from the basin.

Table 3. Proposed water rights for Scenario 2, Variation A.

\begin{tabular}{ccc}
\hline Use & Rights & Annual Duty $\left(\mathrm{m}^{3} /\right.$ day $)$ \\
\hline Municipal & 1 & 14,683 \\
Municipal & 1 & 14,683 \\
Municipal & 1 & 24,471 \\
Municipal & 1 & 24,471 \\
\hline
\end{tabular}

\section{Variation $2 B$}

The SNWA is only granted one groundwater right in the Hot Creek Basin (Table 4). The basis for the ruling from the Nevada State Engineer is that the Hot Creek Basin only has $18,590 \mathrm{~m}^{3}$ /day of groundwater that can be pumped at the perennial yield. Thus, the SNWA limits its wells to just one, which it locates just outside of the CNTA. This well is pumped with an annual duty of $4,457 \mathrm{~m}^{3} /$ day, providing water for people in the greater Las Vegas area. 
Table 4. Proposed water rights for Scenario 2, Variation B.

\begin{tabular}{ccc}
\hline Use & Rights & Annual Duty (m³/day) \\
\hline Municipal & 1 & 4,457 \\
\hline
\end{tabular}

Scenario 3, Mining and Agriculture

With the rise in the price of silver, existing mines located in the Hot Creek Range become economically feasible. Hot Creek Range mining claims are sold to a single large mining company for a reasonable price. The overall goal of the mining company is to sustain silver mining operation by providing a consistent amount of silver to wholesalers while not overproducing, thereby flooding the market.

The emphasis on mining in the region results in a small community of 100 households. Typical major silver and gold mining operations in the state of Nevada employ 16 to 1,641 people per mine (Driesner and Coyner, 2005). The closest active major silver and gold mine, Smoky Valley Common Operation, employs 640 people (Driesner and Coyner, 2005). Thus, the proposed mine for this scenario would be roughly one-sixteenth the size of the closest mining operation and represents mining activities on the low end of the Nevada employee scale. The new residential development to support mining activities is located near existing energy and transportation infrastructure and has a single well. The new residential well is given an allocation of $254 \mathrm{~m}^{3} /$ day. The allocation corresponds to the estimation of annual household water usage of $2.5 \mathrm{~m}^{3} /$ day (Patricia Mulroy, Southern Nevada Water Authority, pers. comm., 2005).

Other water pumping directly related to mining activities does occur. Dewatering pumps are located within the mine to prevent mine shafts from flooding. The dewatering activities result in the transfer of water from the ground to the surface. Although water transfer from the ground to the surface occurs, all this happens within the Hot Creek Range outside the groundwater model boundary. Thus, the model assumes all mine dewatering activities result in surface water recharge where the Hot Creek Range intersects Hot Creek Valley's alluvial plain.

In conjunction with these mining activities comes a desire for some residents to expand agricultural productivity. Subsequently, three new locations for agricultural expansion are purchased from the U.S. Bureau of Land Management. The new locations represent areas where groundwater levels are far enough from the surface to ensure root rot does not occur. The new agricultural locations are allocated groundwater through the use of two wells each for a total of six new agricultural wells. Each new agricultural well is given a water allocation of 2,000 $\mathrm{m}^{3} /$ day as determined from existing center-pivot agricultural activities in Hot Creek Valley. Each new agricultural well is designed to support water demands produced by two center-pivot fields.

Within this scenario, two variations are formulated. The variations represent differing quantities of agricultural land to accommodate the overall State Engineer base-yield amount for the Hot Creek Valley. 


\section{Variation A}

Variation A implements the full, all-out pumping regime as described previously for Scenario 3 (Table 5). All new residential development and new center-pivot agricultural wells are allowed to pump at their maximum rates. Table 5 shows the proposed water rights for Variation A of Scenario 3.

Table 5. Proposed water rights for Scenario 3, Variation A.

\begin{tabular}{cccc}
\hline Use & Rights & Irrigated Hectares & Annual Duty $\left(\mathrm{m}^{3} /\right.$ day $)$ \\
\hline Agriculture & 2 & 400 & 4,000 \\
Agriculture & 2 & 400 & 4,000 \\
Agriculture & 2 & 400 & 4,000 \\
Residential & 1 & N/A & 254 \\
\hline
\end{tabular}

\section{Variation B}

Variation B assumes the State Engineer's perennial yield cannot be exceeded. This assumption reduces the number of new agricultural wells from six to two and maintains the $2,000 \mathrm{~m}^{3}$ /day for the two remaining wells (Table 6). Thus, only half the center-pivot sprinkler systems are installed resulting in a decrease in the number of agricultural fields. Table 6 shows the proposed water rights for Variation B of Scenario 3.

Table 6. Proposed water rights for Scenario 3, Variation B.

\begin{tabular}{cccc}
\hline Use & Rights & Irrigated Hectares & Annual Duty $\left(\mathrm{m}^{3} /\right.$ day $)$ \\
\hline Agriculture & 1 & 200 & 2,000 \\
Agriculture & 1 & 200 & 2,000 \\
Agriculture & 1 & N/A & 254 \\
\hline
\end{tabular}

\section{Scenario 4, Geothermal Energy}

The nation-wide high price of energy drives the search for alternative energy sources. The geothermal activities at hot springs along Hot Creek provide a venue for energy exploration in the region. After exploration, a major geothermal energy company decides to place a geothermal plant where Hot Creek intersects the alluvial plain of Hot Creek Valley. The geothermal plant drills a single well and provides the necessary infrastructure to begin energy production. The geothermal plant has two options for used water. The first is to inject the water back into the ground and the second is to provide holding ponds for infiltration. Managers make a decision to inject the energy producing water back into the ground. Thus, this geothermal energy scenario results in no net loss to the groundwater supply around the plant. Note, that although geothermal electricity production typically yields no net loss or gain of groundwater as the majority of the pumped water is reinjected, it is possible that this activity could result in localized areas of water level change as geothermal sites typically reinject at the margins of the geothermal zone. 


\section{Results for Each Scenario}

The results for each scenario and the current trend reflect the assumption that all current and scenario wells are allowed to extract water at the annual duty for 100 years. Therefore, within each scenario, pumping of the existing wells continues and new wells are added for water extraction. The trend in the current pumping rate for the Hot Creek model domain results in a greater than one-meter drop in groundwater level for an area in the southern portion of the model domain (Figure 11a). The total area where a greater than one-meter decrease in water levels occurs is $230 \mathrm{~km}^{2}$. Currently, the trend in existing conditions is predicted to have no effect on groundwater levels within the CNTA. Note that all results in Figure 11 represent drawdown after 100 years (i.e., 2105).

Scenario 1, proposed wells, results in an approximate doubling in the extent of groundwater level decrease when compared with the existing trend conditions (Figure 11b). The total area where a greater than one-meter decrease in water levels occurs is $530 \mathrm{~km}^{2}$. The scenario's groundwater effect is centered on the six large wells located near the center of the study area. This location contains a concentration of irrigation wells and is the likely cause for the concentration of groundwater loss. Allowance for the refuted wells that are proposed and demonstrated in scenario 1 to pump their annual duty would result in some lowering of groundwater levels, but is predicted to have no effect on groundwater levels within the CNTA.

Variation A of scenario 2, southern Nevada applications, results in the largest extent in one-meter drop in groundwater level for the model domain (Figure 11c). The total area where a greater than one-meter decrease in water levels occurs is $999 \mathrm{~km}^{2}$. Lower groundwater levels occur throughout the basin including within the CNTA. This variation of scenario 2 shows how four wells with high pumping rates can influence groundwater levels throughout the basin.

Variation B of scenario 2 results in a drop in groundwater levels in the northern portion of the study area (Figure 11d). The total area where a greater than one-meter decrease in water levels occurs is $356 \mathrm{~km}^{2}$. The modification of scenario 2 to allow a single well with a reduced pumping rate still causes groundwater levels to drop below the meter threshold at the CNTA because the well is located close to the site. The single well variation of this scenario shows how the location of wells in close proximity to the CNTA can have consequences on CNTA groundwater levels.

Variation A of scenario 3, mining and agriculture, results in an increase in the extent of groundwater level decrease (Figure 11e). The extent is almost double that of the existing trend and the groundwater level decrease follows roughly the same pattern as scenario 1 . The total area where a greater than one-meter decrease in water levels occurs is $435 \mathrm{~km}^{2}$. Both scenario 1 and scenario 3 have a large amount of agricultural water use located in roughly the same geographic location. Thus, this result does not come as a surprise. The scenario and associated variation is predicated to have no effect on groundwater levels within the CNTA.

Variation B of scenario 3 results in a small increase in the extent of groundwater level decrease (Figure 11f). The total area where a greater than one-meter decrease in water levels occurs is $333 \mathrm{~km}^{2}$. The extent of decrease is relatively small with the total change in area being $103 \mathrm{~km}^{2}$ greater than the existing trend. The need to match the potential groundwater 
yield for the basin initiating a drive for fewer agricultural wells causes the result. No effect on groundwater levels below the CNTA occurs.
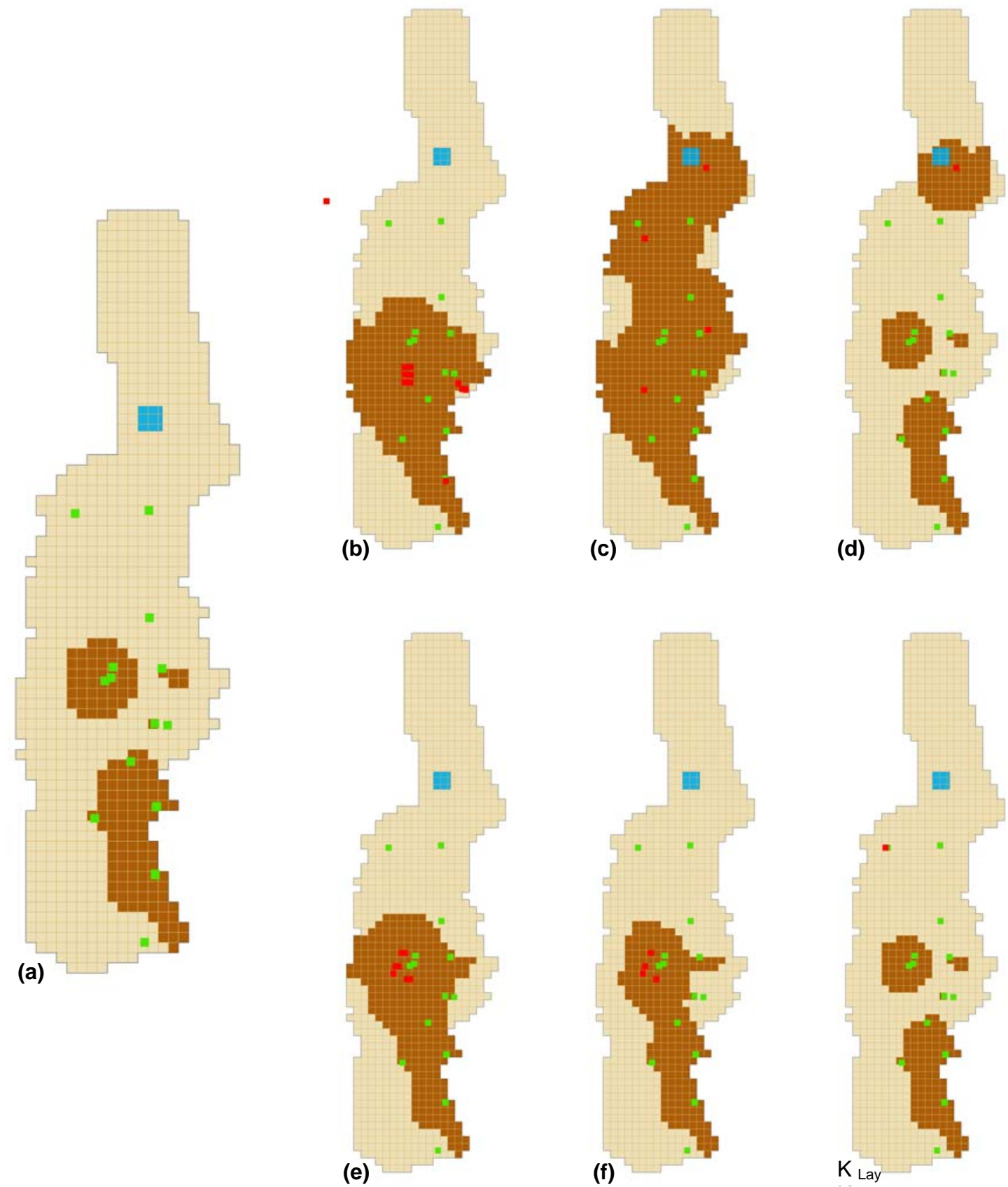

Figure 11. (a) Total groundwater impacts presented for the trend in existing conditions; (b) scenario 1; (c) scenario 2-variation A; (d) scenario 2-variation B; (e) scenario 3-variation A; (f) scenario 3-variation B and (g) scenario 4. Each of the model domain figures shows a greater than one-meter drop in the groundwater level as dark brown, less than one-meter drop in groundwater level as tan, existing wells as green squares, new wells as red squares, and the CNTA as a blue square. 
Scenario 4, geothermal energy, has no effect on groundwater levels beyond that of the existing trend (Figure 11g). Although a single geothermal energy pump is activated, the injection system associated with the plant negates the pump's effect.

The four scenarios and variations show different groundwater effects as a function of pumping rate and spatial location (Table 7). The effect of any planned activity will be dependent on the actual location and planned pumping rate.

Table 7. Groundwater decrease and change from the trend in existing conditions.

\begin{tabular}{lcc}
\hline \multicolumn{1}{c}{ Scenario } & $\begin{array}{c}\text { Total area in 1-m } \\
\text { groundwater decrease }\left(\mathrm{km}^{2}\right)\end{array}$ & $\begin{array}{c}\text { Change in area from trend }\left(\mathrm{km}^{2}\right) \\
\text { and (\% increase) }\end{array}$ \\
\hline Existing Conditions, Trend & 230 & N/A \\
Scenario 1, & 530 & $300(130 \%)$ \\
Scenario 2, Variation A & 999 & $769(334 \%)$ \\
Scenario 2, Variation B & 356 & $126(55 \%)$ \\
Scenario 3, Variation A & 435 & $205(89 \%)$ \\
Scenario 3, Variation B & 333 & $103(45 \%)$ \\
Scenario 4 & 230 & $0(0 \%)$ \\
\hline
\end{tabular}

Although the scenarios analyzed are formulated using existing or proposed trends within the state of Nevada, they are theoretical and intended to demonstrate how the groundwater management tool can be utilized for scenario analysis for groundwater withdrawal. The scenario analysis does indicate that any well located within a relatively close proximity to the CNTA could affect the hydraulic head at CNTA when a moderate pumping rate is applied. The results indicate multiple scenarios can be evaluated under different yield amounts (i.e., unconstrained and the State Engineer-generated potential yield for the basin).

\section{CONCLUSIONS}

The hypothetical future pumping scenarios were developed to demonstrate the utility of the CNTA management model. Some or all of these scenarios may never occur. Nevertheless, the hypothetical scenarios provide insight into the potential consequences of increased pumping within Hot Creek Valley on the groundwater system at CNTA.

The general conclusions that can be drawn from this study include:

1. The CNTA management model provides an easy-to-use computer interface that will allow DOE and state personnel to evaluate the potential impact of proposed pumping within Hot Creek Valley on the CNTA groundwater system.

2. This management model should be used only as a screening tool and not as the final model to evaluate radionuclide transport. Its primary purpose is to highlight when a potential change in pumping may alter radionuclide migration. If this tool suggests that groundwater levels will be impacted at the CNTA, the high-resolution flow and transport model should be revisited to properly predict changes in radionuclide migration.

3. Pumping at current rates in existing wells, as allocated by the Nevada State Engineer, will not cause significant water level declines at CNTA.

4. Increasing pumping rates by including already filed water rights, yet not currently approved (scenario 1), does not cause an impact to the CNTA groundwater system. 
5. The impact of all proposed pumping scenarios is dependent on number of wells, location of wells, and production rate. The management model allows these variables to be taken into account by the user.

\section{REFERENCES}

Daly, C., G. Taylor, and W. Gibson, 1997. The PRISM approach to mapping precipitation and temperature. Pages 10-12 in 10 ${ }^{\text {th }}$ Conference on Applied Climatology, Reno, Nevada.

Dinwiddie, G.A. and L.J. Schroder, 1971. Summary of hydraulic testing in and chemical analysis of water samples from deep exploratory holes in Little Fish Lake, Monitor, Hot Creek, and Little Smoky Valleys, Nevada. U.S. Geological Survey Open-File Report USGS-474-90, 69 p.

Driesner, D. and A. Coyner, 2005. Major mines of Nevada 2004. Mineral industries in Nevada’s economy. Nevada Bureau of Mines and Geology. Special Publication P-16.

Ekren, E.B., E.N. Hinrichs, W.D. Quinlivan and D.L. Hoover, 1973. Geologic map of the Moores Station quadrangle, Nye County, Nevada. U.S. Geological Survey: Miscellaneous Geologic Investigations Map I-756.

Epstein, B.J., 2004. Development and uncertainty analysis of empirical recharge prediction models for Nevada’s desert basins. M.S. thesis, University of Nevada, Reno. 215 p.

Harbaugh, A.W., E.R. Banta, M.C. Hill and M.G. McDonald, 2000. MODFLOW-2000, the U.S. Geological Survey modular ground-water model - User guide to modularization concepts and the ground-water flow process. U.S. Geological Survey Open-File Report 00-92, $130 \mathrm{p}$.

Hoover, D.L., 1968. Lithologic logs of drill holes in the Faultless area, Hot Creek Valley, Nevada. U.S. Geological Survey Technical Letter: Central Nevada-17.

Pohlmann, K., J. Chapman, A. Hassan and C. Papelis, 1999. Evaluation of groundwater flow and transport at the Faultless underground nuclear test, Central Nevada Test Area. Desert Research Institute, Water Resources Center Publication No. 45165, 129 p.

Prudic, D.E., J.R. Harrill and T J. Burbey, 1995. Conceptual evaluation of regional groundwater flow in the carbonate province of the Great Basin, Nevada, Utah, and adjacent States. U. S. Geological Survey Professional Paper 1409-D.

Rush, F.E. and D.E. Everett, 1966. Water-resources appraisal of Little Fish Lake, Hot Creek, and Little Smoky valleys, Nevada. State of Nevada Department of Conservation and Natural Resources, Water Resources-Reconnaissance Series Report 38.

Schwartz, P., 1996. The Art of the Long View. Doubleday. New York, NY. 272 pp.

Shearer, A.W., D.A. Mouat, S.D. Bassett, M.W. Binford, C.W. Johnson, and J.A. Saarinen, 2005. Examining development-related uncertainties for environmental management: Strategic planning scenarios in Southern California. Landscape and Urban Planning, in press. 